\title{
The Survey Program of Ernő Foerk ON THE TÜRbe OF PÉCS
}

\author{
Gergő Máté Kovács, ${ }^{1}$ Krisztina Fehér ${ }^{2}$ \\ ${ }^{1} \mathrm{PhD}$ student, Department of History of Architecture and Monument Preservation, \\ Budapest University of Technology and Economics, Budapest, Hungary \\ kovacsmg@eik.bme.hu \\ ${ }^{2} \mathrm{PhD}$ student, Department of History of Architecture and Monument Preservation, \\ Budapest University of Technology and Economics, Budapest, Hungary \\ feher.krisztina@eptort.bme.hu
}

\begin{abstract}
:
Ernö Foerk (1868-1934) born 150 years ago has significant oeuvre in the field of monument preservation and architectural education. As professor, one of his achievements was the organisation of summer survey camps named as 'szünidei felvételek' (vacation records) which was also accessible in published form. In the year of 1917 under his supervision, his students have surveyed all the scored Ottoman monuments of Hungary. In the following year these survey drawings were published with a brief summary of the history of Ottoman architecture in the territory of Hungary. Our paper is to submit the general circumstances of the Ottoman survey program supervised by Ernö Foerk with its historical background and the analysis of the methodology of the survey by the example of the türbe of Pécs.
\end{abstract}

Keywords: History of Ottoman Architecture, Hungarian-Turkish Architectural Relations, türbe of Idris Baba, monument survey, methodology

\section{INTRODUCTION}

Strongly inspired by the approach of Friedrich Schmidt and Imre Steindl, Foerk has started his career at Joseph Polytechnicum, and at Building Industry Academy (Épitöipariskola), which has later become the Hungarian Royal Public Higher Architectural Industrial School (Budapest Magyar Királyi Állami Felsö Építöipari Iskola). At the same time in 1911 he became the member of the National Committee of Monuments (Müemlékek Országos Bizottsága, MOB) [1]. His most significant publication works had close connection to his educational activity presenting the survey of several historical monuments. From the year of 1912, the Hungarian Royal Public Higher Architectural Industrial School announced the so-called 'Vacation Surveys ' for its students with the supervision of Foerk. In 1912 and 1914, the summer surveys were organised in Transylvania, and in 1913 in Northern Hungary [2]. Between 17-29 $9^{\text {th }}$ June 1917 supported by the Hungarian state and the MOB, Foerk supervised a study-tour with the aim of surveying and the Ottoman buildings in Bács, Pécs and Szigetvár. Ottó Szőnyi has also participated in the journey as an architect of the MOB. In $17^{\text {th }}$ September 1917, Foerk noted in his diary that the text of the 'Turkish Booklet is ready' as a summary of his studies [3]. 
This work published by Foerk was not the first catalogue which mentioned the Ottoman buildings of Hungary, since the research of several scholars had already covered the subject of Ottoman artefacts from the $17^{\text {th }}$ century [4]. In 1855, a list of the monuments of Buda prepared by the Lieutenancy of Buda and edited by Antal Auguszt, has already mentioned the tomb of Gül Baba. Besides, in the same year, a summary of the Ottoman buildings was published in Vasárnapi Újság [5]. In 1867, during the official visit of Sultan Abdülaziz, the doctor of Császár Bath, Franz Xaver Linzbauer, as well as Lajos Némethy also published a summary of the Ottoman buildings of Buda [6], and the Péter Gerecze's inventory of historical monuments in 1906 included Ottoman heritage [7]. Besides these scholars, Foerk was the first architect to research this topic in a wider range, enriching the aspects with an architectural point of view, with the aim of covering the whole country, and moreover evaluating it in a wider context [8]. Before the description of his works on the Ottoman buildings, firstly the brief historical background of his survey shall be taken stock of.

\section{THE SURVEY PROGRAM OF ERNŐ FORK ACCORDING TO THE ASPECT OF THE HUNGARIAN - TURKISH RELATIONS OF THE AGE}

Foerk has supervised and managed the survey of the Ottoman buildings with the aim of its scientific research, however, the introduction of the collection contains interpretation in an ideological way. The introduction begins with the definition of his task as the activity of the Turks in Hungary used to be adjudged according to military aspects - as Foerk writes-therefore, the cultural aspect also has to be emphasized. However, Foerk describes the additional aim of this activity as "supplying justice to our closest relative of genus' [9], since where "they have settled, a new culture has been planted' which 'differed from the civilisation of the Western nations in appearance, but supplied equivalent to the people of the conquered provinces'. Therefore, the Turanian interpretation is visible in his introduction, which is a general feature of the similar works of the age.

The political relations of the end of the $18^{\text {th }}$ century resulted a more suggestive European interest on the art and architecture located in the East. Despite its complex and varied features, this romantic interest and unique perception of the age can be covered with the term of 'Orientalism'. Since the Ottoman Empire has covered the significant part of the aforementioned territory, the artistic and architectural artefacts oftentimes refer to the art in the Ottoman lands. The same period the Ottoman Empire and the Austro-Hungarian Monarchy has been faced with similar political situations, and approaches. Among the various pan (pangermanic, panamerican, panslavic) movements, Hungarians were also tend to research their hypothetical origins. It was also manifested in researching the common cultural and architectural heritage, which was toned with political and ideological aspects resulting from Turanism [10], referring to Inner-Asia; mainly, to the nations of Turkic origin [11].

In Hungary, the institutionalised appearance of Turanian ideology was officiating under the name of the 'Hungarian Turanian Society'. The partnership of 'Tahsil-i Sanayi Cemiyeti' (Industrial Education Association) in Istanbul also supported young engineers to apply for short-term scholarships in Hungary. Moreover, the issue of the students came to the territory of Hungary for education was officially declared by the circular on the Duties of the Oriental Culture Centre and the education of Turkish youths placed in Hungarian Schools, which was launched in 25th August 1916 [12]. During the period, 7 Turkish students were studying at the Hungarian Royal Public Higher Architectural Industrial School, which was recorded in the 1917/18 year Report of the institution. They were: Abdurrahim Ali (class: I a), Ali Djevat (I b), Ismael Kemali (I b), Mustafa Sahin (I b), Kiamil Mehmed (II a), Nuri Muammer (II A) AND 
Rüstem Semih (II a) [13]. However, two students have left the institution, and in the 1918/19 academic year continued their education in the Royal Joseph Polytechnicum - one of them was Semih Rüstem, according to his course book [14]. The three Turkish students, who participated at the surveying programs were Mehmet Kamil and Mustafa Sahin and Semih Rüstem [15].

Besides the survey program in the territory of Hungary, Foerk has participated study tours in the Balkans. The tours were organised officially by the Hungarian Academy of Sciences. The main organiser was Pál Teleki, who was the essential member of the Turanian Society's vicepresidency. One tour was organised directly after the survey trip of Foerk with his students, between 24-27 $7^{\text {th }}$ September 1917 [16]. He travelled to Albania and Serbia. About the journey, one report exist which was addressed to the Hungarian Academy of Sciences [17]. Also, a booklet was published with the title of 'Balkan Letters' [18]. His second journey was held after the finishing of the book of the Ottoman buildings', and the aforementioned presentation of the survey. This journey began on $22^{\text {nd }}$ March 1918, and the location was in Serbia, from Belgrade to Uzice [19].

The result of the Ottoman buildings' survey program as well as the activity of the Turkish students, has received the attention of the diplomatic representatives of the Ottoman Empire, since counsellor general Ahmet Hikmet and Abdüllatif efendi has visited the Academy in March 1918. The official visit has been recorded in the aforementioned yearbook of the institute [20]. The occasion of the visit was probably the presentation of the Ottoman survey program by Ernö Foerk. According to the diary of Foerk, it was on $13^{\text {th }}$ March 1918 [21].

\section{THE OTTOMAN BUILDINGS RECORDED BY ERNŐ FOERK AND HIS STUDENTS}

The survey program contained 20 buildings and details from various cities of Hungary (Budapest, Eger, Érd, Pécs, Szigetvár, Bács, Temesvár), both the northern and southern territories and Transylvania. (Figure 1) The drawings were made by 2nd and 3rd year students of the Academy. (See: Appendix) The claim of the effort for completeness has been appeared in the fact, that Professor Ignác Kúnos, the eminent scholar of the Ottoman language and Turkish literature was also involved to the survey works. Some Ottoman inscriptions on the tombstones [22] in Temesvár were registered by Semih Rüstem, who could write in Ottoman, and was translated to Hungarian by Kúnos. It expresses the interdisciplinarity of his program.

As an introduction, a summary text was also published written by Foerk, which submits a brief functional typology of the Ottoman buildings. Despite the Turanian ideological aspect of the interpretation, the text attempts to evaluate the age according to the architectural values which has been created by the Ottomans. Also express the fact of the low amount of constructions -'stagnation' as he describes- which is explained the continuous wartime and struggles, and also the frequent change of high-level officers - namely the beylerbeys [23].

The value of the work of Foerk was to supply primary architectural resources and database not only for the monument preservation works, but also to educate and transmit the importance of the detailed survey of the buildings for the next generation. And the uniqueness was, that the subject of this education was the building group of Ottoman architecture in Hungary. Moreover, not only the monument preservation was educated according to this program, but this architectural period was inserted to the education of architectural history. In 1929, Foerk publishes the book with the title of 'The Brief History of the Hungarian Building Art upon Hungarian Monuments' [24]. This work publishes summaries of 8 architectural periods with examples illustrated also with his own surveys. The aim of the volume is both the education of the architectural history in Hungary prior to monument preservation. 

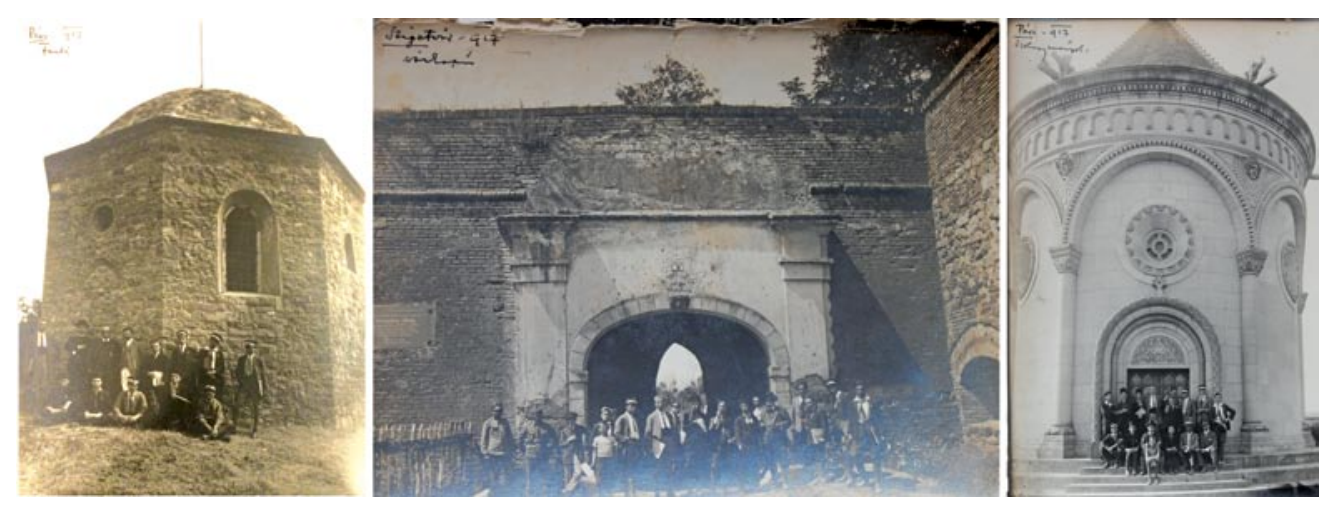

Figure 1. The participants of the survey trip in front of the türbe of Pécs, the main gate of the castle of Szigetvár and the mausoleum of the Zsolnay family in Pécs, in the year of 1917.

On the photos we can see Ernő Foerk as well as the three Turkish students wearing fez, source: Archive of Gyula Forster National Heritage and Asset Management Centre)

The book, which is concerned with the Roman, Ancient Christian, Romanesque, Gothic, Renaissance, Baroque architecture and the building culture of the $19^{\text {th }}$ Century devotes a chapter with 10 pages for the Ottoman (according to the denomination of Foerk: Turkish) Architecture in Hungary. There were previous examples, that architectural summaries publish the aforementioned age systematically. However, the significance of the work is, that Foerk adds the Hungarian Ottoman architecture to a book with the general purpose of the education of architectural history.

Both his schoolbook, and the survey book, a functional typology is introduced, which contained baths, wells, praying buildings, dervish monasteries and "funeral chapels" (mausolea). Besides the fact that this functional typology can be detailed according to the person of the founder or the building construction, building technology, the typology of Foerk was accurate according to the age.

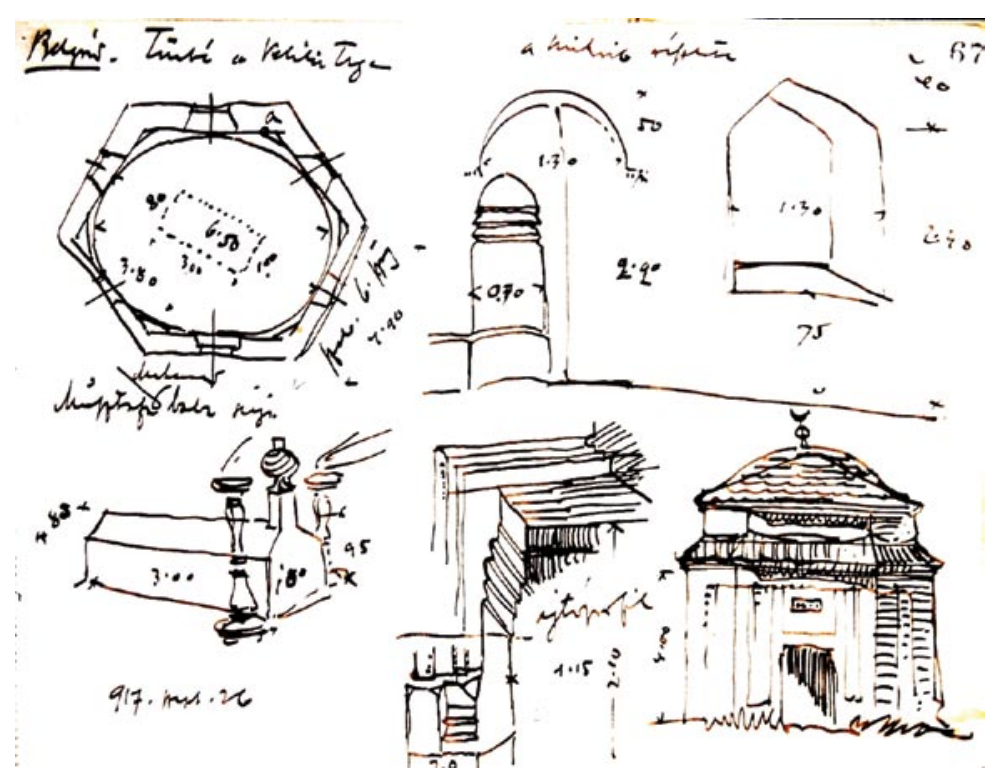

Figure 2. Survey drawing sketch of the türbe in Belgrade by Ernő Foerk drawn 
on 26th September 1917, source: MMA MÉM MDK Archives 3/19., 67.

The elaboration of the work of Foerk escalates on research of analogues, which fact is expressed in his diary definitely. During his study tour to the Balkans, Foerk surveys Ottoman buildings in Albania and Serbia [25]. Observing his survey sketch made about the türbe in Belgrade, we can see his careful work. The plan and facade are both surveyed - moreover the material of the roof covering is marked. Some details, e.g. the profile of the door is recorded. However, Foerk also recorded the historical interior of the building. On the drawing the ritual coffin in the interior (sanduka) and the two candle holders (samdan) are recorded. (Figure 2) These object might be only furniture, however in the building type of mausolea (türbe) these are essential functional elements for the complexity of the buildings, therefore it is important to be recorded. Especially the direction of the sanduka, which refers to the direction of the tomb under the surface, since the sanduka traditionally parallel to the tomb. Consequently, in this case the survey method of Foerk is accurate.

During the past century, since the survey program, several modifications were made on the buildings- moreover, in some cases the further researches carried out new information on the original function [26]. In the following paragraphs, on the example of the türbe in the city of Pécs, the modifications of the building and the methodology of the survey will be analysed.

\section{THE TÜRBE OF IDRIS BABA IN PÉCS}

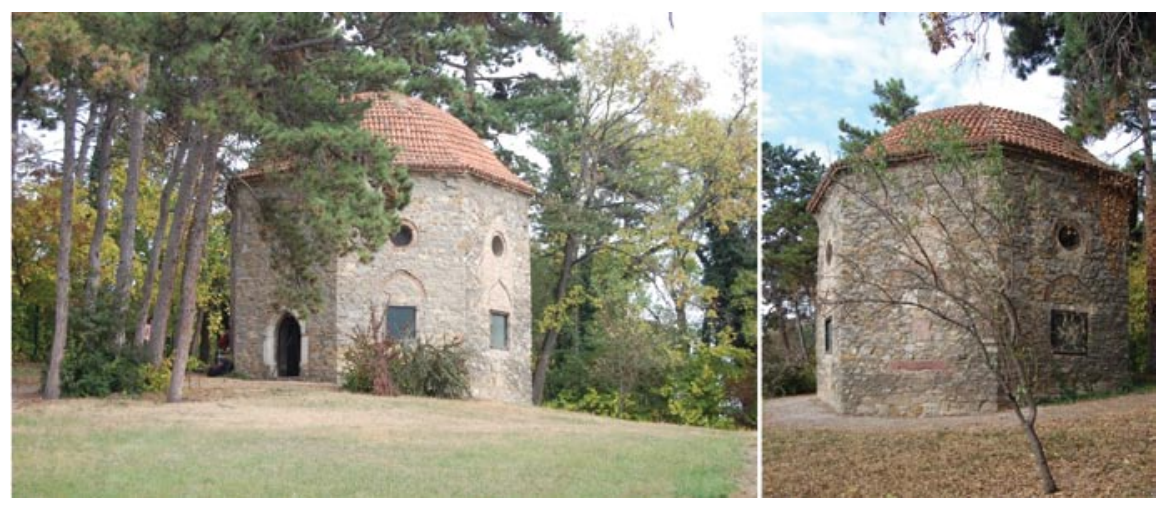

Figure 3. The türbe of Idris Baba in Pécs. South-western and

South-eastern view, source: authors' photos, 2018)

The octagonal planned funeral memorial building - mausoleum - covered with a hemisphere dome built on the grave of Idris baba is located on the North-western part of Pécs [27]. (Figure 3) The building is one of the two, still standing türbe building in the territory of Hungary [28]. Despite the fact that the plan and space structure of the building is adequate to the classical, 15-17 Century Ottoman türbes, the used material represent a provincial feature [29]. The walls are constructed by inhomogeneous stone material. The building has two rows of windows. The dome is covered with ceramics. These three features differ from the other, still standing Ottoman mausoleum, the türbe of Gül Baba, and more typical in the Balkans, as we can see on Foerk's survey about the türbe in Belgrade. (Figure 2) The original entrance was on the opposite façade to the qibla.

Following the Ottoman period, the buildings which were newly erected during the era were mainly vanished. Those buildings which have been remained and visible nowadays, 
mainly became private property - or the property of the Jesuit order. The building which was created around the $1600 \mathrm{~s}$, became the chapel of the Jesuits around 1690s. Therefore, many modifications were made on them according to functional necessities, as it has happened with the türbe of Idris Baba. Between 1793-1903 the building has functioned as the gunpowderstore of the city. Since 1903 the türbe was the chapel of the children's hospital. In 1913, István Möller made reconstruction works. The survey program of Ernő Foerk was the first, coherent architectural drawn survey on the building, 4 years following the works of István Möller. In 1942, Gyula Gosztonyi made drawings about the building. Between 1960-61, general archaeological excavations, surveys were made under the leadership of the architect Ferenc Erdei and archaeologists Győző Gerö and Mária Sándor [30]. This was followed by the restoration of the building according to the reconstruction plans of Károly Ferenczy with the aim of submitting its Ottoman conditions [31]. In our present days, the building becomes actual again, since during the last years, discussions have been started about a new restoration project in the near future [32].

\subsection{The Description and Methodology of the Survey Drawing Supervised by Ernö Foerk}

By the analysis of Foerk's survey methods, the influence of his professors and colleagues is to be taken into consideration. As the student of the Vienna master-builder, Friedrich von Schmidt and later the colleague and assistant of Imre Steindl, the essential role of monument survey in Foerk's education was obvious. [33] The methodology of monuments survey has changed quickly through generations. The typical method of the Wiener Bauhütte (led by Schmidt) and the 'Müegyetemi Épitészhallgatók Egyesülete' (led by Steindl) in the 19th century tended to follow sophisticated artistic features while the drawings of high standard graphics certainly represented a professional knowledge of the structural system of the historical buildings. (Figure 4)

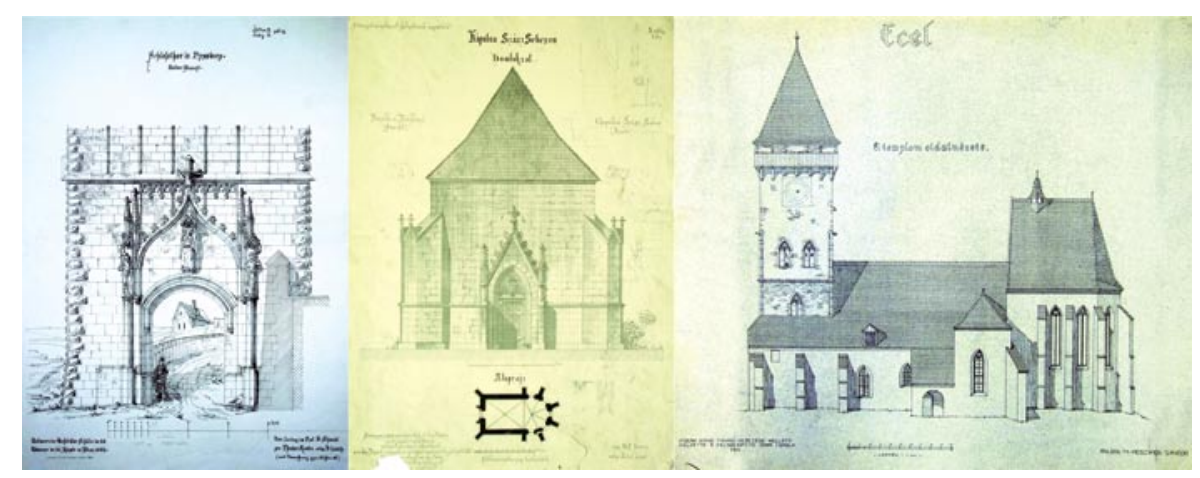

Figure 4. Examples of the drawings of the Wiener Bauhütte, of 'Magyarországi Müemlékek'by the 'Müegyetemi Épitészhallgatók Egyesülete' and surveys supervised by Foerk, source: Plan Collection of BME Department of History of Architecture and Monument Preservation, no.102945, 102545, 103767.

However, the purist logic has frequently ignored any modifications of later periods aside from the Middle Ages, thus the survey drawings generally shown a quasi-reconstruction of the building, in other words, an ideal medieval form. In this manner, the geometry and the details of the drawings are highly questionable, hardly showing the real status of the buildings. 
Being the successor of Steindl's generation, such as István Möller, Gyula Wälder, Kálmán Lux or Károly Csányi, Foerk's survey methods have been different from the traditions of the Wiener Bauhütte. As one of Foerk's colleague in the MOB, Möller has worked out a method arguing with purist principles, by evaluating and accurately documenting each sign of all historical periods. Möller's survey method has been more practical, serving as the foundation of further restauration works. Foerk however was more likely to follow the traditional principles, that the students of the Wiener Bauhütte and the 'Müegyetemi Épitészhallgatók Egyesülete' applied. His students' survey drawings tended to be schematic and in certain details different from the reality, while great efforts have been focused on the aesthetic and graphic quality. The layout inscriptions, titles and dating also has been uniformed and designed, similarly to the 19th-century drawings. (Figure 4)

The survey of the türbe of Idris Baba in Pécs from 1917 also follow these features. (Figure 5) The drawings that have been made by Foerk's student, János Sinogli, [34] serve as important sources regarding the colourful history of the building. Two plans, three sections and the western elevation of the octagonal türbe have been documented. (Figure 5)

As one of the most important circumstances of the survey can be mentioned that the türbe was renovated by István Möller four years earlier in 1913 by the order of the MOB [35]. The building has been formerly used as powder tower since 1793 when all its windows and doors were walled up and covered while a new door was opened on the South-eastern façade. [36] Möller has investigated the building and by removing the coating he discovered the traces of the original openings. [37] As the first door from the Ottoman period had been changed for a new stone portal of pointed arch in the $17^{\text {th }}$ century, Möller has identified the building, by mistake, as a Gothic chapel, later modified as an Ottoman türbe. [38] With the intention of collecting all Ottoman monuments of Hungary, Foerk and his students' survey of 1917 has documented the status of the building right after Möller's renovation and before any other later modification.

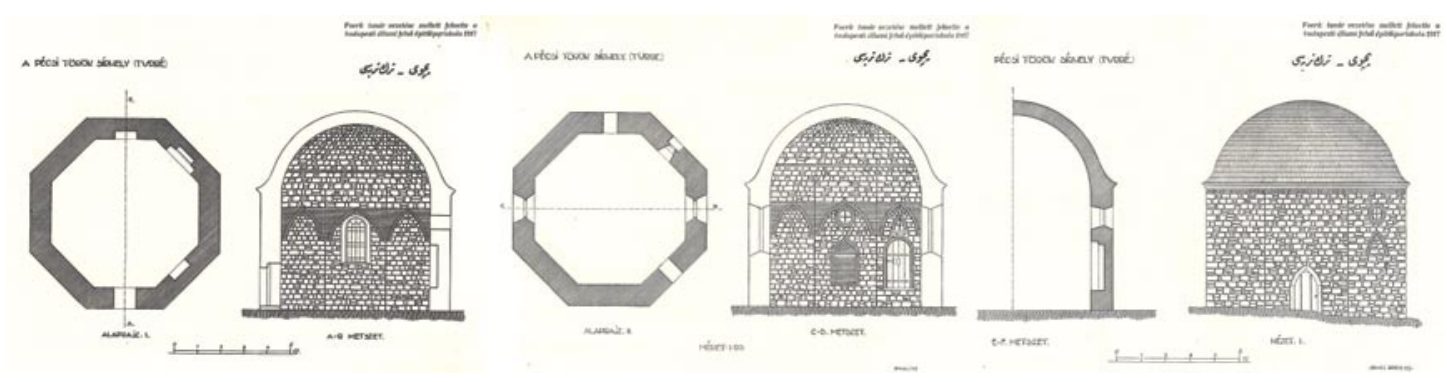

Figure 5. Survey drawings of the türbe of Idris Baba in Pécs. Drawn by János Sinogli, supervised by Ernő Foerk in 1917. Source: Foerk, E. Török emlékek Magyarországban. [Turkish Relics in Hungary] In: A Magyar Királyi Állami Felső Építő Ipariskola Szünidei Felvételei 1912-

1942. Reprint kiadás. [The Vacation Records of Hungarian Royal Public Higher Architectural Industrial School 1912-1942. Reprint Edition.], Budapest, TERC, 2002. 18-20.

\subsection{The Comparison of the Current Conditions and the Survey Drawing Supervised by Ernő Foerk}

Aside from their documentary value, the drawings have to be regarded with meticulous criticism. Although several latter changes were worked out during the $20^{\text {th }}$ century, comparing the surveys with the current status of the facades, significant anomalies can be detected. The case of the traces of the Ottoman portal can be considered as the most curious. 
In Sinogli's drawings no signs of the original door can be found, however it was certainly discovered by Möller, with notable brick remains marking its original position and rough dimensions. (Figure 6) The lack of these signs in the texture of the North-western wall in the drawings is more noticeable in regard to the theme of the survey program of the year focusing on Ottoman buildings.

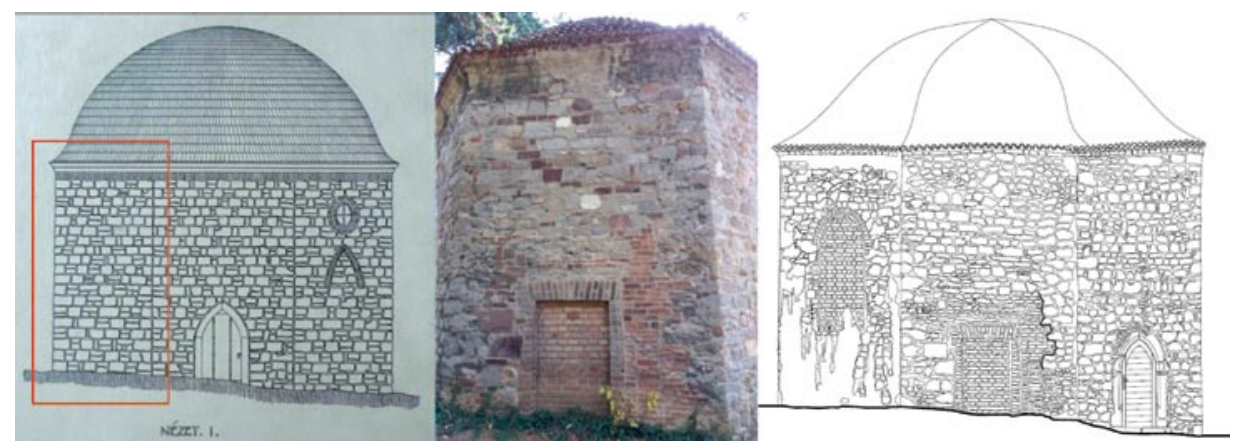

Figure 6. Drawing of the North-western façade by Sinogli, supervised by

Foerk in 1917 and the current status of the façade (MMA MÉM MDK Plan collection 13213/a, photo and survey drawing of the authors, 2015)

The accurate form of some lintels represents another significant anomaly. Namely in the case of the blind lintel (of a walled up window) of ogee arch in the South-western façade and the upper window of reduced dimensions with a semi-circular lintel in the South-eastern façade, both have been drawn with pointed arch. All these imprecisions confirm that the methodology of the surveys that Foerk has guided were closer to the traditions of the former generations, as similar anomalies also can be detected in the drawings of the Wiener Bauhütte or the edition of 'Magyarországi Müemlékek', where sometimes more attention was focused on the overview, the medieval features and the ideal construction of the building than on the exhaustive representation of the correct form of all details. [39]

\section{CONCLUSION}

The survey program of the Ottoman buildings in the territory of Hungary organised and supervised by Ernő Foerk was not the first catalogue which mentioned the Ottoman buildings of Hungary. However, Foerk was the first architect who researched this topic in a wider range, and an interdisciplinary way, enriching the aspects with an architectural point of view, with the aim of covering the whole country. The survey program surveyed 20 buildings and details from various cities of Hungary made by 2nd and 3rd year students of the Hungarian Royal Public Higher Architectural Industrial School. The value of the work of Foerk was to supply primary architectural resources and database not only for the monument preservation works, but also for education. Both this survey book, and a schoolbook based on his surveys introduced a functional typology based on his surveys. However, he had the intention to research analogues, since during his study tour to the Balkans, Foerk survey Ottoman buildings in Albania and Serbia.

This program submitted the first, coherent architectural drawn survey on the türbe of Idris Baba in Pécs 4 years following the restoration works of István Möller, documenting the status of the building right after Möller's renovation and before any other later modification. Aside from their documentary value, the drawings have to be regarded with meticulous criticism, 
since the methodology of the surveys were closer to the traditions of the former generations. Similar anomalies also can be detected in the drawings of the Wiener Bauhütte or the edition of 'Magyarországi Müemlékek', where sometimes more attention was focused on the overview and the ideal construction of the building than on the exhaustive representation of the correct form of all details.

His work also contains an ideological interpretation of Turanism which is not unprecedented in the early $20^{\text {th }}$ century. During the period, 7 Turkish students were studying at his institution, and 3 of them (Mehmet Kamil, Mustafa Sahin and Semih Rüstem) participated at the surveying programs. Moreover, the students and the program received the attention of the diplomatic representatives of the Ottoman Empire in March 1918.

Besides the Turanian ideological aspect of the interpretation, and the anomalies of the methodology his work attempts to evaluate the age according to the architectural values which has been created by the Ottomans in the territory of Hungary.

\section{ACKNOWLEDGMENTS}

We are grateful to Pál Ritoók for his help during our research at the Archives of Hungarian Museum of Architecture and Monument Preservation Documentation Centre (Magyar Építészeti Múzeum és Műemlékvédelmi Dokumentációs Központ, MMA MÉM MDK) Archives. We would like to express our thankfulness having the opportunity to research at the Plan Collection of BME Department of History of Architecture and Monument Preservation. In addition, we are indebted to Gergely Domonkos Nagy for the possibility of participating in the international conference organised for the anniversary of the birth of Ernő Foerk at Szent István University, Ybl Miklós Faculty of Architecture and Civil Engineering.

\section{REFERENCES}

[1.] Pusztai L., Foerk Ernő müemlékvédelmi munkásságáról. [On the Monument Preservation Works of Ernő Foerk] in Pusztai L., Hadıк A. Az O.M.F. Magyar Építészeti Múzeumának kiállítása Foerk Ernő (1868-1934) építész műveiből. [The Exhibition of the National Inspectorate of Monuments about the Works of Ernő Foerk (1868-1934) Architect] Budapest: O.M.F., 1984.14.

[2.] Kovács, G. The History of the Summer Survey of the Hungarian Royal Public Higher Architectural Industrial School - in the Mirror of Collection Resources, Ybl Yournal of Built Environment 7(2019) 2.

[3.] MMA MÉM MDK, Diary of Ernő Foerk, 71.

[4.] In the late 17th century, Jakob Tollius copied certain inscriptions in the mosque of Érsekújvár (today Nové Zámky, Slovakia), and in the $19^{\text {th }}$ century, Josef Hammer-Purgstall copied, translated and published some inscriptions from the Suleiman Djami at Szigetvár, both of which remain in situ. Ottoman architectural remains, such as the Hamam of Valide Sultana in Eger and the Djami of Malkoç Bey in Siklós aroused the interest of Flóris Rómer. See: GERő, Gr. The History of Ottoman-Turkish Archaeological research in Hungary, In Archaeology of the Ottoman Period in Hungary, eds. Ibolya Gerelyes, Gyöngyi Kovács, Budapest: Hungarian National Museum, 2003; Hammer-Purgstall, J. 'tudósítása a' pécsi fötemplomban található keleti felírásokról [Report on the Oriental Excavation in the Main Church of Pécs]', Magyar Academiai Értesitö, 4 (1844) 2, 5563.

[5.] ANon. Török épületmaradványok hazánkban, [Turkish Building Fragments in our Country], Vasárnapi Ujság 2 (1855) 11, 85-86., Sudár, B. Dzsámik és mecsetek a hódolt Magyarországon. [Djamis and Mosques in the Ottoman Hungary] Budapest: MTA Bölcsészettudományi Kutatóközpont, Történettudományi Intézet, 2014. 30.

[6.] Linzbauer, F. X. Führer Seiner Majestat Sultan Abdul Aziz Khan bei Besichtigung der Türkischen Baudenkmäler in Ofen [Guide of the Turkish Monuments in Pest for His Majesty Sultan Abdul Aziz Han], Pest, 1867.; Némethy, L. Török mecsetek Budán. [Turkish Mosques in Buda] Budapest, 1878. 
[7.] Gerecze, P. Magyarország müemlékei [Monuments of Hungary], Vol 2. Budapest: Hornyánszky, 1906.

[8.] Besides the fact that many researches and monographies were made on the Ottoman buildings in Hungary, the next summaries, which directly follows the work of Foerk and contain both survey drawings and archival researches were published in the 1970s-1980 by the Turkish scholar, Ekrem Hakkı Ayverdi and his colleagues, (See: AyvErdi, E. H., Avrupa'da Osmanlı Mimârî Eserleri. Romanya, Macaristan I. [Ottoman Architectural Monuments in Europe. Romania, Hungary I.], İstanbul: İstanbul Fetih Cemiyeti, 1977.) and on the Hungarian side, by Győző Gerő and József Molnár. (MoLnár, J. A török világ emlékei Magyarországon. Budapest: Corvina, 1976.; Gerö, Gy.. Az oszmán-török épitészet Magyarországon. (Dzsámik, türbék, fürdők). Müvészettörténeti füzetek 12. kötet. Budapest, 1980.)

[9.] Foerk, E. Török emlékek Magyarországban. [Turkish Relics in Hungary] In: A Magyar Királyi Állami Felső Építő Ipariskola Szünidei Felvételei 1912-1942. Reprint kiadás. [The Vacation Records of Hungarian Royal Public Higher Architectural Industrial School 1912-1942. Reprint Edition.], Budapest, TERC, 2002. 1.

[10.] OLÁH, P. „A török és a magyar turanizmus kapcsolata a 20. század első felében.” [The Relationship of the Turkish and Hungarian Turanism in the First Half of the 20th Century], Keletkutatás, 2012 spring.; ABLonczy, B. Keletre, magyar! A magyar turanizmus története. [To East, Hungarian! The History of Hungarian Turanism. Budapest: Jaffa, 2016.

[11.] The architects working within the ideology of Turanism used Eastern, Central Asian, sometimes Islamic motifs on their works, as we can see on the Museum of Applied Arts designed by Ödön Lechner and Gyula Pártos in Budapest, between 1891-1896, the plans of Historical Hall by Ignác Alpár designed for the Millennial Exhibition competition in 1893. The 'Hungarian Scientific Institution of Constantinople' (Konstantinápolyi Magyar Tudományos Intézet) organised scientific, historical research of Byzantine and Ottoman architecture, art history and archaeology, purchasing scholarships for researchers to work in Constantinople. One of the most significant persons who researched at the Institution was the architect Károly Kós (1883-1977), who carried out research not only on the Byzantine and Ottoman architectural heritage of Constantinople but also on the history of its urban development and housing; in this aspect, he emphasised the importance of its preservation. See: AKyürek, G., A Comparative Reading of the Pursuit into the 'East' for National Expression in Turkish and Hungarian Architecture. In Thirteenth International Congress of Turkish Art, eds.: Ibolya Gerelyes and Géza Dávid, Budapest: Hungarian National Museum, 2009. pp. 59-60.; Kós, K. İstanbul. Şehir Tarihi ve Mimarisi. [Istanbul. Urban History and Architecture]. İstanbul: Yeditepe, 2017.

[12.] In Hungarian: 1916. aug. 25. 56.154 VI. B. Körrendelet. A Keleti Kultur-Központ feladata s a magyar iskolákban elhelyezett török ifjak neveléséröl. See: the Yearbook of the Academy in the years 1916/17. 65.

[13.] Sснорiтsch, L. A Budapesti M. Kir. Állami Felső Építőipariskola Értesítője az 1917/18. iskolai évről. Huszadik Év. [The Report of the Hungarian Royal Public Higher Architectural Industrial School about the 1917/17 Academic Year. Twentieth Year.] Budapest, 1918. 12-13.

[14.] Archives of Budapest University of Technology and Economics, BMEL_EPK_K-17_Szemih_Rusztem, 1918. See: GüMüş, M. D. A Turkish Architect at Technical University of Budapest: Semih Rüstem. Periodica Polytechnica Architecture 46, 1. (2015): 39.

[15.] Semih Rüstem (1898-1946), the important link of the Turkish-Hungarian architectural relations of the early $20^{\text {th }}$ century,has started his education at the first institute for architectural education in the Ottoman Empire: at Sanayi-i Nefise Mektebi (Fine Arts Academy) in Istanbul, after that travelled to Budapest with the support of Turanian Association. He was firstly studied at Hungarian Royal Public Higher Architectural Industrial Schoolaccording to the yearbooks, and participated the survey program - he draw the türbe of Gül Baba in Buda, and the tombstones of Temesvár. In 1918, he continued his education in Royal Joseph Polytechnicum as his course book reports. After returning to Istanbul, between 1929-1933 he worked as freelance architect. As an example, he designed the Adana Slaughterhouse Project and used modernist influenced forms and Ottoman Revivalism, with elements from his experiences of Budapest. The same time, he was instructor at "İstanbul Fine Arts Academy"- as it can be read from his letters wrote to Ernő Foerk. His letters, which he wrote to Ernő Foerk in 1923, were signed in two languages, French and Hungarian, as: Sémihe Rustéme Séfay, Architecte, Professeur, École Imperiale D’Arts et Métiers / Szemih Rusztem Szefai, Építész, Török Császári Felső Építő Ipariskolai Tanár (Semih Rüstem Sefai, Turkish Imperial Higher Construction Trade Academy Instructor). In 1933, Semih Rüstem was appointed to the Ankara Development /Housing Directorate as director. In this position he was an important figure of the Early Republican era of the Turkish Architecture. During the period called the Second National Architectural Movement (Turkish: İkinci Ulusal Mimarlık Akımı), Rüstem worked in the construction of the new republic capital, Ankara, according to the urban plan of German architect, Herman Jansen. In this function, he travelled once more to Hungary: to Szeged, as an article in 1933 reports. Then he described 
the contemporary development process of the new capital and also remembers to his education in Hungary. See: MAGYAR, L. Szemih Rüsztem utja a magyar müegyetemtől Ankara közmunkatanácsának igazgatói állásáig [The Way of Semih Rüstem from the Hungarian Polytechnicum until the Director Chair of the Ankara Public Work Directorate]. Délmagyarország, Volume 9 (23rd June 1933), No 140, 4.; GüMüş, M. D. A Turkish Architect at Technical University of Budapest: Semih Rüstem. Periodica Polytechnica Architecture 46, 1. (2015): 38-45. https://doi.org/10.3311/PPar.8205; AsLANoĞLu, İ. Erken Cumhuriyet Dönemi Mimarlığı (1923-1938). [The Architecture of the Early Republican Period (1923-1938).] İstanbul: Bilge Kültür Sanat, (1980) 2010.; BozdoĞAN, S. Modernizm ve Ulusun İnşası. Erken Cumhuriyet Türkiyesi’nde Mimari Kültür. [Modernism and Nation Building: Turkish Architectural Culture in the Early Republic]. İstanbul: Metis, 2012. The letters of Semih Rüstem wrote in $27^{\text {th }}$ April 1923 can be found in MMA MÉM MDK.

[16.] $26^{\text {th }}$ September 1917: Belgrade, 29 $9^{\text {th }}$ September 1917: Üszküb (Skopje), $1^{\text {st }}$ October 1917: Mitrovica, $6^{\text {th }}$ October 1917: Decsán, $7^{\text {th }}$ October 1917: Gyakova (Gjakovë). $9^{\text {th }}$ October 1917: Prizren, 16 ${ }^{\text {th }}$ October 1917: Szkutari (Skodra), $17^{\text {th }}$ October

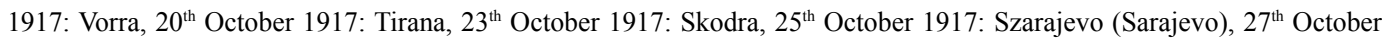
1917: Budapest.

[17.] Foerk E. Foerk Ernő építész, a Felső Építő Ipariskola tanára jelentése. [Report of Architect Foerk Ernő, the Lecturer of the Hungarian Royal Public Higher Architectural Industrial School]. MMA MÉM MDK

[18.] FoERK E. Balkáni levelek.[Balkan Letters]. Budapest: Korvin Testvérek, 1918. [MMA MÉM MDK]

[19.] Vukoszávlyev, Z. Foerk Ernö szerb-ortodox templom-tipológiája. [The Serbian Orthodox Church Typology of Ernö Foerk]. Presented on the Symposium organised for the 150th Anniversary of the birth of Ernő Foerk at Szent István University Miklós Ybl Faculty of Architecture and Civil Engineering, $20^{\text {th }}$ November 2019

[20.] The Yearbook has mentioned them as 'Achmet Hikmet török fökonzul Ö Exellentiája és Abdul Latif török föpap' [His Excellency Achmet Hikmet Turkish Consul General and Abdul Latif Turkish 'Pontifical'] who were 'excessively interested in the situation of the Turkish youths'. See: Sснорiтsch, L. A Budapesti M. Kir. Állami Felső Építőipariskola Értesítője az 1917/18. iskolai évről. Huszadik Év. [The Report of the Hungarian Royal Public Higher Architectural Industrial School about the 1917/17 Academic Year. Twentieth Year.] Budapest, 1918. 8.

[21.] MMA MÉM MDK Archives, Diary of Ernő Foerk, 73.

[22.] Acun, H., Türk Kültüründe Taşlar [Stones in the Turkish Culture], Ankara: Atatürk Kültür Merkezi Yayınları 2014.16.

[23.] FoERK, E. Török emlékek Magyarországban. [Turkish Relics in Hungary] In: A Magyar Királyi Állami Felső Építő Ipariskola Szünidei Felvételei 1912-1942. Reprint kiadás. [The Vacation Records Hungarian Royal Public Higher Architectural Industrial School 1912-1942. Reprint Edition.], Budapest, TERC, 2002.1.

[24.] Foerk E. A magyar építőmüvészet rövid története: magyar mủemlékek nyomán [The Brief History of the Hungarian Building Art upon Hungarian Monuments] Kecskemét, 1929.

[25.] MMA MÉM MDK Archives, Diary of Ernő Foerk, 73.

[26.] E.g. the rectangular planned, two floored brick building in Szigetvár was named as "ritual church", however, according to the researches the original function was residential.

[27.] Idris Baba belonged to the bektashi order of the dervishes according to the clarification of Balázs Sudár. Sudár, B. A pécsi Idrisz Baba-türbe. [The Türbe of Idris Baba in Pécs], Budapest: Forster Gyula National Heritage and Asset Management Centre, 2013. The identification of the building was made during the early 1900's according to the records of Ibrahim Pechevi.

[28.] The exact amount of the former memorial buildings is still an opened question. According to Ekrem Hakkı Ayverdi, the number of kabrs and türbes are minimum 17. Balázs Sudár imparts 18 for the minimal number of türbes in the territory of Hungary.According to Ekrem Hakkı Ayverdi the number of kabr and türbe buildings are at least 17, according to Balázs Sudár, there was at least 18 türbes in the territory of Hungary, however, this number can be also 22. Ayverdi, E. H., Avrupa'da Osmanlı Mimârî Eserleri. Romanya, Macaristan I. [Ottoman Architectural Monuments in Europe. Romania, Hungary I.], İstanbul: İstanbul Fetih Cemiyeti, 1977. 84.; Sudár, B. A pécsi Idrisz Baba-türbe. [The Türbe of Idris Baba in Pécs], Budapest: Forster Gyula National Heritage and Asset Management Centre, 2013. 39., 70-91.

[29.] Kuban, D. Osmanlı Mimarisi [Ottoman Architecture]. İstanbul: Yem, 2007.; RaBB P. 'We are all servants here!' Mimar Sinan - architect of the Ottoman Empire”, Periodica Polytechnica Architecture, 44., 1. (2013), pp. 17-37. doi: https://doi.org/10.3311/ PPar.7444.[30.] Gerö, Gy. - Sándor, M. Pécs-Idrisz Baba türbe (Nyár utca 8.) Ásatás és épületfeltárás 1960. [Pécs, Türbe of Idris Baba (8. Nyár Street) Excavation and Building Survey 1960.], Forster Gyula National Heritage and Asset Management Centre Plan Archive. Reg. no.: 05461; 
[31.] Ferenczy, K. Idrisz Baba türbe. Müemlékhelyreállítás müszaki dokumentációja. [Türbe of Idris Baba. The Technical Documentation of the Monument Preservation], (Országos Mủemléki Felügyelőség, 1961.) Forster Gyula National Heritage and Asset Management Centre Plan Archive. Reg. no.: 09349.

[32.] The important aim of the new restoration projects is to avoid all the which damages its constructions, to arrange its environment and also to answer some detailed questions which are related to architectural details (e.g. arrangement of interior, covering of floor, construction of the covering of dome, the question of the alem, the size of the windows and parapets, and the question of entrance).

[33.] Hajdú, V. - Prakfalvi, E. Ed. Lapis Angularis II, Budapest: OMvH Magyar Építészeti Múzeum [Hungarian Architectural Museum], 1998. 17-19.

[34.] Foerk, E. Török emlékek Magyarországban. [Turkish Relics in Hungary] In: A Magyar Királyi Állami Felső Építő Ipariskola Szünidei Felvételei 1912-1942. Reprint kiadás. [The Vacation Records Hungarian Royal Public Higher Architectural Industrial School 1912-1942. Reprint Edition.], Budapest, TERC, 2002. 18-20. Between 1914 and 1915, excavations were carried out for the remains of Gül Baba; at the same time, the türbe of Gül Baba was also renovated by István Möller, although this internal and external renovation obliterated much of the detail from previous ages.

[35.] Sudár, B. A pécsi Idrisz Baba-türbe. [The Türbe of Idris Baba in Pécs], Budapest: Forster Gyula National Heritage and Asset Management Centre, 2013. 61.

[36.] MMA MÉM MDK Archives 303/2

[37.] SudÁr, B. A pécsi Idrisz Baba-türbe. [The Türbe of Idris Baba in Pécs], Budapest: Forster Gyula National Heritage and Asset Management Centre, 2013. 61.

[38.] Sudár, B. A pécsi Idrisz Baba-türbe. [The Türbe of Idris Baba in Pécs], Budapest: Forster Gyula National Heritage and AssetManagement Centre, 2013. 61.

\section{Appendix: The list of the surveyed Ottoman buildings by Ernő Foerk and his Student}

\begin{tabular}{|c|c|c|c|c|c|c|}
\hline \multirow[t]{2}{*}{ Location } & \multirow[t]{2}{*}{ Title of drawing } & \multirow{2}{*}{$\begin{array}{l}\text { Translation } \\
\text { of the title }\end{array}$} & \multirow{2}{*}{$\begin{array}{l}\text { Building } \\
\text { type }\end{array}$} & \multirow[t]{2}{*}{ Drawing type } & \multicolumn{2}{|l|}{ Surveyor student } \\
\hline & & & & & Name & $\begin{array}{l}\text { Acad. } \\
\text { Year }\end{array}$ \\
\hline Budapest & $\begin{array}{l}\text { Buda és Pest } \\
\text { látképe 1686-ban }\end{array}$ & $\begin{array}{l}\text { The View } \\
\text { of Buda and } \\
\text { Pest in } 1686\end{array}$ & -gravure- & -gravure- & Dezső Elsner & 3 \\
\hline Budapest & $\begin{array}{l}\text { Mecset Pesten. } \\
\text { Fischer von } \\
\text { Erlach után }\end{array}$ & $\begin{array}{l}\text { Mosque in Pest. } \\
\text { After Fischer } \\
\text { von Erlach }\end{array}$ & mosque & view & Károly Barta & 3 \\
\hline Budapest & $\begin{array}{l}\text { Budapest. } \\
\text { Gülbaba sírja. }\end{array}$ & $\begin{array}{l}\text { Budapest. Tomb } \\
\text { of Gülbaba. }\end{array}$ & türbe & $\begin{array}{l}2 \text { plans, } 1 \text { cross } \\
\text { section and } 1 \text { facade }\end{array}$ & Semih Rüstem & 2 \\
\hline Pécs & $\begin{array}{l}\text { Pécs. Jakováli } \\
\text { Hasszán Pasa } \\
\text { dsámija }\end{array}$ & $\begin{array}{l}\text { Pécs. Djami } \\
\text { of Yakovali } \\
\text { Hasan Pasha }\end{array}$ & $\begin{array}{l}\text { djami with } \\
\text { minaret }\end{array}$ & $\begin{array}{l}4 \text { plans, } 2 \text { cross } \\
\text { sections, } 2 \text { plans and } \\
\text { details of minaret }\end{array}$ & $\begin{array}{l}\text { Gyula Bayer } \\
\text { (just initials: } \\
\text { BGY1917) }\end{array}$ & \\
\hline Pécs & $\begin{array}{l}\text { Chasim pascha } \\
\text { dsamija Pécsett }\end{array}$ & $\begin{array}{l}\text { The Djami of } \\
\text { Khasim Pasha } \\
\text { in Pécs }\end{array}$ & $\begin{array}{l}\text { djami with } \\
\text { minaret }\end{array}$ & $\begin{array}{l}1 \text { plan, } 1 \text { cross } \\
\text { section, } 2 \text { facades, } \\
\text { details (mukarnas) }\end{array}$ & Gyula Bayer & \\
\hline Pécs & $\begin{array}{l}\text { Pécsi török } \\
\text { sírhely (Turbé.) }\end{array}$ & $\begin{array}{l}\text { The Turkish } \\
\text { Tomb of Pécs } \\
\text { (Turbe) }\end{array}$ & türbe & $\begin{array}{l}2 \text { plans, } 2 \text { cross } \\
\text { sections, } 1 \text { section, } \\
1 \text { facade }\end{array}$ & János Sinógli & 2 \\
\hline
\end{tabular}




\begin{tabular}{|c|c|c|c|c|c|c|}
\hline Szigetvár & $\begin{array}{l}\text { Szigetvár } \\
\text { plébániatemplom }\end{array}$ & $\begin{array}{l}\text { The Parish } \\
\text { Church of } \\
\text { Szigetvár }\end{array}$ & djami & $\begin{array}{l}2 \text { plans, } 2 \text { cross } \\
\text { sections, } 1 \text { facade }\end{array}$ & $\begin{array}{l}\text { Sándor Bende } \\
\text { and Béla Loksa }\end{array}$ & 3 \\
\hline Szigetvár & $\begin{array}{l}\text { Szigetvár } \\
\text { - Sztalaktit } \\
\text { részletek a } \\
\text { róm. kath. } \\
\text { templomból 1:10 }\end{array}$ & $\begin{array}{l}\text { Szigetvár - } \\
\text { stalactyte details } \\
\text { from the Roman } \\
\text { Catholic church }\end{array}$ & $\begin{array}{l}\text { details } \\
\text { - munkarnas }\end{array}$ & details & $\begin{array}{l}\text { József } \\
\text { Merendy III. }\end{array}$ & 3 \\
\hline Szigetvár & $\begin{array}{l}\text { Szigetvár } \\
\text { várbeli mecset }\end{array}$ & $\begin{array}{l}\text { Mosque in } \\
\text { the Castle of } \\
\text { Szigetvár }\end{array}$ & mosque & $\begin{array}{l}1 \text { plan, } 2 \text { cross } \\
\text { sections, } 4 \text { facades, } 1 \\
\text { plan of the minaret }\end{array}$ & Béla Németh & 3 \\
\hline Szigetvár & $\begin{array}{l}\text { Szigetvári } \\
\text { rituális templom }\end{array}$ & $\begin{array}{l}\text { Ritual church } \\
\text { of Szigetvár }\end{array}$ & $\begin{array}{l}\text { ritual } \\
\text { church? } \\
\text { (later } \\
\text { identified as } \\
\text { residental } \\
\text { house) }\end{array}$ & $\begin{array}{l}2 \text { plans, } 1 \text { cross } \\
\text { section, } 1 \text { facade }\end{array}$ & Ferenc Schäfer & \\
\hline Eger & $\begin{array}{l}\text { Egri minaré } \\
\text { helyreállítva }\end{array}$ & $\begin{array}{l}\text { The } \\
\text { reconstructed } \\
\text { minaret of Eger }\end{array}$ & minaret & $\begin{array}{l}3 \text { plans, } 1 \text { cross section, } \\
1 \text { facade, details }\end{array}$ & József Unger & 3 \\
\hline Érd & Török minaré & Turkish minaret & minaret & $\begin{array}{l}3 \text { plans, } 1 \text { cross } \\
\text { section, } 1 \text { facade }\end{array}$ & József Merendy & 3 \\
\hline Bács & $\begin{array}{l}\text { Bács török } \\
\text { fürdő romjai }\end{array}$ & $\begin{array}{l}\text { Ruins of Turkish } \\
\text { Bath in Bács }\end{array}$ & hamam & 2 plans, 2 cross sections & Semih Rüstem & 2 \\
\hline Pécs & $\begin{array}{l}\text { Részletek a } \\
\text { Pécsi Városi } \\
\text { Múzeumban }\end{array}$ & $\begin{array}{l}\text { Details in the } \\
\text { City Museum } \\
\text { of Pécs }\end{array}$ & details & details & József Merendi & 3 \\
\hline $\begin{array}{l}\text { Bács, } \\
\text { Szigetvár }\end{array}$ & $\begin{array}{l}\text { Mosómedencék } \\
\text { a Bácsi és } \\
\text { Szigetvári } \\
\text { fürdőkből }\end{array}$ & $\begin{array}{l}\text { Washing Pools } \\
\text { from the Baths } \\
\text { from Bács and } \\
\text { Szigetvár }\end{array}$ & $\begin{array}{l}\text { hamam taş } \\
\text { teknesi }\end{array}$ & & József Merendi & 3 \\
\hline Buda & $\begin{array}{l}\text { Török fürdő } \\
\text { Budán Fischer v } \\
\text { Erlach rajza után }\end{array}$ & $\begin{array}{l}\text { Turkish Bath } \\
\text { in Buda after } \\
\text { the drawing of } \\
\text { Fischer v Erlach }\end{array}$ & 1lica & plan and facade & Károly Barta & 3 \\
\hline Budapest & $\begin{array}{l}\text { Budapesti } \\
\text { Királyfürdő }\end{array}$ & $\begin{array}{l}\text { The Király Bath } \\
\text { in Budapest }\end{array}$ & ilica & $\begin{array}{l}2 \text { plans, } 2 \text { cross } \\
\text { sections, } 1 \text { facade }\end{array}$ & Mihály Kollár & 2 \\
\hline Budapest & $\begin{array}{l}\text { Budapesti } \\
\text { Császárfürdő } \\
\text { Gőzfürdője }\end{array}$ & $\begin{array}{l}\text { The Steam Bath } \\
\text { of the Császár } \\
\text { Bath in Budapest }\end{array}$ & 1lica & $\begin{array}{l}2 \text { plans, } 2 \text { cross } \\
\text { sections, details } \\
\text { (mukarnas) }\end{array}$ & $\begin{array}{l}\text { Károly Barta, } \\
\text { Izsó May, } \\
\text { József Fischer }\end{array}$ & $3,3,2$ \\
\hline Budapest & A Rudas Fürdő & The Rudas Bath & 1lica & $\begin{array}{l}2 \text { plans, } 3 \text { cross } \\
\text { sections, details } \\
\text { (mukarnas) }\end{array}$ & $\begin{array}{l}\text { Izsó May, Pál } \\
\text { Schwitzer, } \\
\text { Sándor Bende }\end{array}$ & $3,3,3$ \\
\hline Temesvár & Török sírkövek & $\begin{array}{l}\text { Turkish } \\
\text { tombstones }\end{array}$ & $\begin{array}{l}\text { mezartaş1 } \\
\text { (tombstone) }\end{array}$ & $\begin{array}{l}2 \text { facade, details } \\
\text { (scripts) }\end{array}$ & $\begin{array}{l}\text { Semih Rüstem } \\
\text { (translation: } \\
\text { Ignác Kúnos) }\end{array}$ & 2 \\
\hline
\end{tabular}

